\title{
Investigations on the reactivity of arylantimony halides with $\mathbf{N}, \mathbf{O}$-donor ligands
}

\author{
PILLI V V N KISHORE ${ }^{\mathrm{b}}$, JUNAID ALI ${ }^{\mathrm{a}}$, GUJJU NARASIMHULU ${ }^{\mathrm{a}}$ and \\ VISWANATHAN BASKAR ${ }^{\mathrm{a}, *}$ \\ ${ }^{a}$ School of Chemistry, University of Hyderabad, Hyderabad, Telangana 500 046, India \\ ${ }^{\mathrm{b}}$ Chemistry division, Department of Sciences and Humanities, VFSTR (Deemed to be University), Guntur, \\ Andhra Pradesh 522 213, India \\ E-mail: vbsc@uohyd.ac.in
}

MS received 23 March 2018; revised 22 May 2018; accepted 23 May 2018; published online 13 July 2018

\begin{abstract}
The reactions of organoantimony(V) halides with N,O-donor ligands in presence of a base were investigated. The synthesis and crystal structure of three novel organoantimony $(\mathrm{V})$ compounds $\left(\mathrm{Ph}_{2} \mathrm{Sb}\right)_{2}(\mathrm{Q})_{2}(\mathrm{O})_{2} \mathbf{1},\left(\mathrm{Ph}_{3} \mathrm{Sb}\right)(\mathrm{PM}) \mathrm{Cl} 2$ and $\left(\mathrm{Ph}_{2} \mathrm{Sb}\right)(\mathrm{TEA}) 3$ [where $\mathrm{Q}=8$-hydroxyquinoline, $\mathrm{PM}=$ 2-pyridinemethanol and TEA $=$ triethanolamine] are reported herein. 1 crystallizes as a dimer resulting in the formation of a four-membered $\mathrm{Sb}_{2} \mathrm{O}_{2}$ ring while $\mathbf{2}$ and $\mathbf{3}$ are monomeric in the solid state. Interestingly, compound 3 crystallizes in orthorhombic chiral space group $P 2{ }_{1} 2_{1} 2_{1}$ and is a rare example of spontaneous chirality exhibited in organoantimony $(\mathrm{V})$ compounds.
\end{abstract}

Keywords. Organoantimony $(\mathrm{V})$ compounds; $\mathrm{N}$,O-donor ligands; $\mathrm{Sb}_{2} \mathrm{O}_{2}$ ring; structural elucidation; spontaneous chirality.

\section{Introduction}

Since organoantimony $(\mathrm{V})$ compounds have potential applications in the fields like catalysis ${ }^{1}$ and biology, ${ }^{2}$ there has been continued interest in the synthesis and structural characterization of novel organoantimony $(\mathrm{V})$ compounds. Generally, these compounds have been synthesized by the reaction of tri/di-organoantimony $(\mathrm{V})$ halides with protic ligands like carboxylates, phosphinates and alkoxides in the presence of a base resulting in the formation of diphenyl antimony(V) oxo/chloro carboxylates and phosphinates whose nuclearity vary from mono, di, tetra, octa and nona-nuclear forms. ${ }^{3-9}$ Organoantimony compounds, particularly with antimony in the oxidation state of +5 , can exist in coordination numbers as high as seven or eight due to its hypervalent nature. ${ }^{10-15}$ Very recently, the chemistry of mono-organoantimony compounds have started gaining interest since the ability of organostibonic acids to act as inorganic cryptand incorporating $\mathrm{d}^{5}$ and $\mathrm{d}^{10}$ metal ions in their cavity was reported. ${ }^{16}$ Further, the isolation

\footnotetext{
*For correspondence
}

of the first molecular arylstibonic acids and subsequently the use of mixed arylstibonate/phosphonate clusters as proligands for the assembly of multinuclear cobalt clusters have increased the interest in organoantimony compounds in general. ${ }^{17} \mathrm{~A}$ careful investigation of the literature reports of organoantimony $(\mathrm{V})$ compounds revealed that mostly protic ligands with oxo donors have been used as ligands to generate novel organoantimony(V) compounds. ${ }^{18-24}$ Hence, we investigated the reactions of organoantimony $(\mathrm{V})$ halides with N,O-donor ligands in presence of a base with the aim of isolating new structural forms. Synthesis and crystal structure of three novel organoantimony $(\mathrm{V})$ compounds $\left(\mathrm{Ph}_{2} \mathrm{Sb}\right)_{2}(\mathrm{Q})_{2}(\mathrm{O})_{2} \mathbf{1},\left(\mathrm{Ph}_{3} \mathrm{Sb}\right)(\mathrm{PM}) \mathrm{Cl} 2$ and $\left(\mathrm{Ph}_{2} \mathrm{Sb}\right)(\mathrm{TEA}) 3$ are reported herein.

\section{Experimental}

\subsection{Materials and measurements}

8-Hydroxyquinoline, 2-pyridinemethanol, triethanolamine, solvents and other common reagents were used as purchased 
from commercial sources. $\mathrm{Ph}_{2} \mathrm{SbCl}_{3}$ and $\mathrm{Ph}_{3} \mathrm{SbCl}_{2}$ were synthesized using literature procedures. ${ }^{25,26}$ Infrared spectra were recorded on a JASCO-5300 FT-IR spectrometer as $\mathrm{KBr}$ pellets. The ${ }^{1} \mathrm{H}$ and ${ }^{13} \mathrm{C}$ solution NMR spectra were recorded on a Bruker DRX 400 instrument. Elemental analysis was performed on a Flash EA Series 1112 CHNS analyzer.

\subsection{Synthesis of complexes (1-3)}

For compounds $\mathbf{1}$ and $\mathbf{3}$, general synthetic method used is as follows. Organoantimony starting material $\left(\mathrm{Ph}_{2} \mathrm{SbCl}_{3}\right)$ and respective ligands [8-hydroxyquinoline (for $\mathbf{1}$ ), triethanolamine (for 3)] were dissolved separately in toluene. The ligand was deprotonated by adding triethylamine and the deprotonated ligand was added to organoantimony halide in toluene. The solution was then stirred for $6 \mathrm{~h}$, filtered and evaporated to afford a gelly material. Crystals [pale yellow (1) and colorless (3)] suitable for single-crystal X-ray studies were grown from dichloromethane/hexane or toluene in 5 days. Compound $\mathbf{2}$ was also prepared in a way similar to $\mathbf{1}$ and 3 except that both antimony compound $\left(\mathrm{Ph}_{3} \mathrm{SbCl}_{2}\right)$ and the ligand 2-pyridinemethanol were taken in toluene followed by slow addition of the base. Colorless crystals suitable for single crystal X-ray studies were grown from toluene in a week.

\subsection{Synthesis of $\left(\mathrm{Ph}_{2} \mathrm{Sb}\right)_{2}(\mathrm{Q})_{2}(\mathrm{O})_{2}(\mathbf{1})$}

$\mathrm{Ph}_{2} \mathrm{SbCl}_{3} \quad(0.20 \mathrm{~g}, \quad 0.523 \mathrm{mmol})$, 8-hydroxyquinoline $(0.22 \mathrm{~g}, 1.56 \mathrm{mmol})$ and $\mathrm{Et}_{3} \mathrm{~N}(0.15 \mathrm{~g}, 1.56 \mathrm{mmol})$. Yield: $0.08 \mathrm{~g}$ (35.08\%, based on the weight of antimony). M.p.: $272{ }^{\circ} \mathrm{C}$. Anal. Calcd. for $\mathrm{C}_{42} \mathrm{H}_{32} \mathrm{Sb}_{2} \mathrm{O}_{4} \mathrm{~N}_{2}$ : C, 57.8; H, 3.69; N, 3.20\%. Found: C, 57.65; H, 3.61; N, 3.28\%. IR $\left(\mathrm{cm}^{-1}\right.$, KBr pellet): 3045 w, $1601 \mathrm{~m}, 1574 \mathrm{~m}, 1498 \mathrm{~s}, 1462 \mathrm{~s}, 1429 \mathrm{~m}$, $1375 \mathrm{~m}, 1323 \mathrm{~m}, 1273 \mathrm{~m}, 1107 \mathrm{~s}, 1062 \mathrm{~m}, 821 \mathrm{w}, 781 \mathrm{w}, 731 \mathrm{~s}$, $696 \mathrm{~s}, 538 \mathrm{~m}, 453 \mathrm{w} .{ }^{1} \mathrm{H}$ NMR in $\mathrm{CDCl}_{3}: \delta 8.91-8.54(\mathrm{~m}, 4 \mathrm{H})$, 7.81-7.60 (m, 6H), 7.50-7.39 (m, 12H), 7.36-7.27 (m, 8H), 7.02-6.86 (m, 2H). ${ }^{13} \mathrm{C} \mathrm{NMR}$ in $\mathrm{CDCl}_{3}: \delta 152.23,142.36$, 136.12 , 133.11, 132.88, 129.81, 128.53, 128.29, 127.76, $121.86,117.90,110.00 \mathrm{ppm}$.

\subsection{Synthesis of $\left(\mathrm{Ph}_{3} \mathrm{Sb}\right)(\mathrm{PM}) \mathrm{Cl}$ (2)}

$\mathrm{Ph}_{3} \mathrm{SbCl}_{2}$ (0.30 g, $\left.0.707 \mathrm{mmol}\right)$, 2-pyridinemethanol (0.15 g, $1.41 \mathrm{mmol})$ and $\mathrm{Et}_{3} \mathrm{~N}(0.14 \mathrm{~g}, 1.41 \mathrm{mmol})$. Yield: $0.13 \mathrm{~g}$ ( $37.03 \%$, based on the weight of antimony). M.p.: $134^{\circ} \mathrm{C}$. IR ( $\mathrm{cm}^{-1}, \mathrm{KBr}$ pellet): $3053 \mathrm{w}, 1601 \mathrm{~m}, 1572 \mathrm{~m}, 1477 \mathrm{~s}, 1462 \mathrm{~s}$, $1431 \mathrm{~s}, 1363 \mathrm{~m}, 1288 \mathrm{~m}, 1076 \mathrm{~s}, 1045 \mathrm{~m}, 761 \mathrm{w}, 733 \mathrm{~s}, 690 \mathrm{~s}$, $466 \mathrm{~m}$.

\subsection{Synthesis of $\left(P h_{2} S b\right)(T E A)(3)$}

$\mathrm{Ph}_{2} \mathrm{SbCl}_{3}(0.30 \mathrm{~g}, 0.784 \mathrm{mmol})$, triethanolamine $(0.11 \mathrm{~g}$, $0.784 \mathrm{mmol})$ and $\mathrm{Et}_{3} \mathrm{~N}(0.15 \mathrm{~g}, 2.35 \mathrm{mmol})$. Yield: $0.12 \mathrm{~g}$ (30.8\%, based on the weight of antimony). M.p.: $232{ }^{\circ} \mathrm{C}$. Anal. Calcd. for $\mathrm{C}_{18} \mathrm{H}_{22} \mathrm{SbO}_{3} \mathrm{~N}$ : C, 51.2; H, 5.25; N, 3.31\%.
Found: C, 51.36; H, 5.18; N, 3.41\%. IR $\left(\mathrm{cm}^{-1}\right.$, KBr pellet): 3045 w, 2918 w, 2879 m, 2847 s, 1462 s, $1431 \mathrm{~m}, 1304 \mathrm{~m}$, $1267 \mathrm{~m}, 1153 \mathrm{~m}, 1105 \mathrm{~s}, 1076 \mathrm{~m}, 881 \mathrm{~s}, 754 \mathrm{~m}, 736 \mathrm{~m}, 700 \mathrm{~s}$, $594 \mathrm{~m}, 516 \mathrm{~s}, 470 \mathrm{w} .{ }^{1} \mathrm{H} \mathrm{NMR}$ in $\mathrm{CDCl}_{3}: \delta 7.99-7.64(\mathrm{~m}$, $6 \mathrm{H}), 7.43-7.35(\mathrm{~m}, 4 \mathrm{H}), 4.41-3.76(\mathrm{~m}, 6 \mathrm{H}), 3.13-2.62(\mathrm{~m}$, $6 \mathrm{H}) .{ }^{13} \mathrm{C} \mathrm{NMR}$ in $\mathrm{CDCl}_{3}: \delta 135.04,134.61,134.06,128.77$, $128.65,128.25,58.66,56.92$, ppm.

\subsection{Single crystal X-ray structure determination}

Single crystal X-ray data collection (for 1, 2 and $\mathbf{3}$ ) was carried out at $100(2) \mathrm{K}$ on a Bruker Smart Apex CCD area detector $\operatorname{system}(\lambda($ Mo $K \alpha)=0.71073 \AA)$, with a graphite monochromator. The data were reduced using SAINT PLUS, ${ }^{27}$ and the structures were solved using SHELXS-97 ${ }^{28}$ and refined using SHELXL-97. All non-hydrogen atoms were refined anisotropically. Selected crystal parameters for $\mathbf{1} \mathbf{- 3}$ are given in Table S1 (in Supplementary Information). CCDC 864363, 864364 and 864365 contain the supplementary crystallographic data for compounds $\mathbf{1}, \mathbf{2}$ and $\mathbf{3}$ respectively. These data can be obtained free of charge via www.ccdc.cam.ac.uk/ data_request/cif, by emailing data_request@ccdc.cam.ac.uk, or by contacting The Cambridge Crystallographic Data Centre, 12, Union Road, Cambridge CB2 1EZ, UK; fax: +44 1223 336033 .

\section{Results and Discussion}

The methodology used for synthesizing $\mathbf{1}$ is as follows. 8-Hydroxyquinoline was dissolved in toluene and deprotonated by adding an equimolar ratio of triethylamine. Diphenylantimony trichloride was separately dissolved in toluene to which was added the solution of deprotonated 8-hydroxyquinoline and the mixture was stirred for $6 \mathrm{~h}$ at room temperature. The solution was then filtered to remove the triethylamine hydrochloride formed and the filtrate evaporated under high vacuum to yield a gelly material which was dissolved in dichloromethane, layered with hexane and left undisturbed. After 5 days, pale yellow crystals of $\mathbf{1}$, suitable for single-crystal X-ray characterization were isolated in good yields. For the synthesis of $\mathbf{2}$ and $\mathbf{3}$, a similar synthetic procedure was followed except that the reagents used were different (Scheme 1). For the synthesis of $\mathbf{2}$, triphenylantimony dichloride and 2-pyridinemethanol were reacted in presence of base triethylamine and in the case of $\mathbf{3}$, diphenylantimony trichloride was reacted with triethanolamine in presence of triethylamine. In the case of $\mathbf{2}$, crystals were grown from toluene whereas in 3 crystals suitable for single crystal X-ray characterization were obtained by dichloromethane/hexane layering method in a week's time. Compounds $\mathbf{1}$ and $\mathbf{3}$ were subjected to standard spectroscopic and analytical techniques. The detailed experimental methods with the exact molar ratios of the reagents used along with 


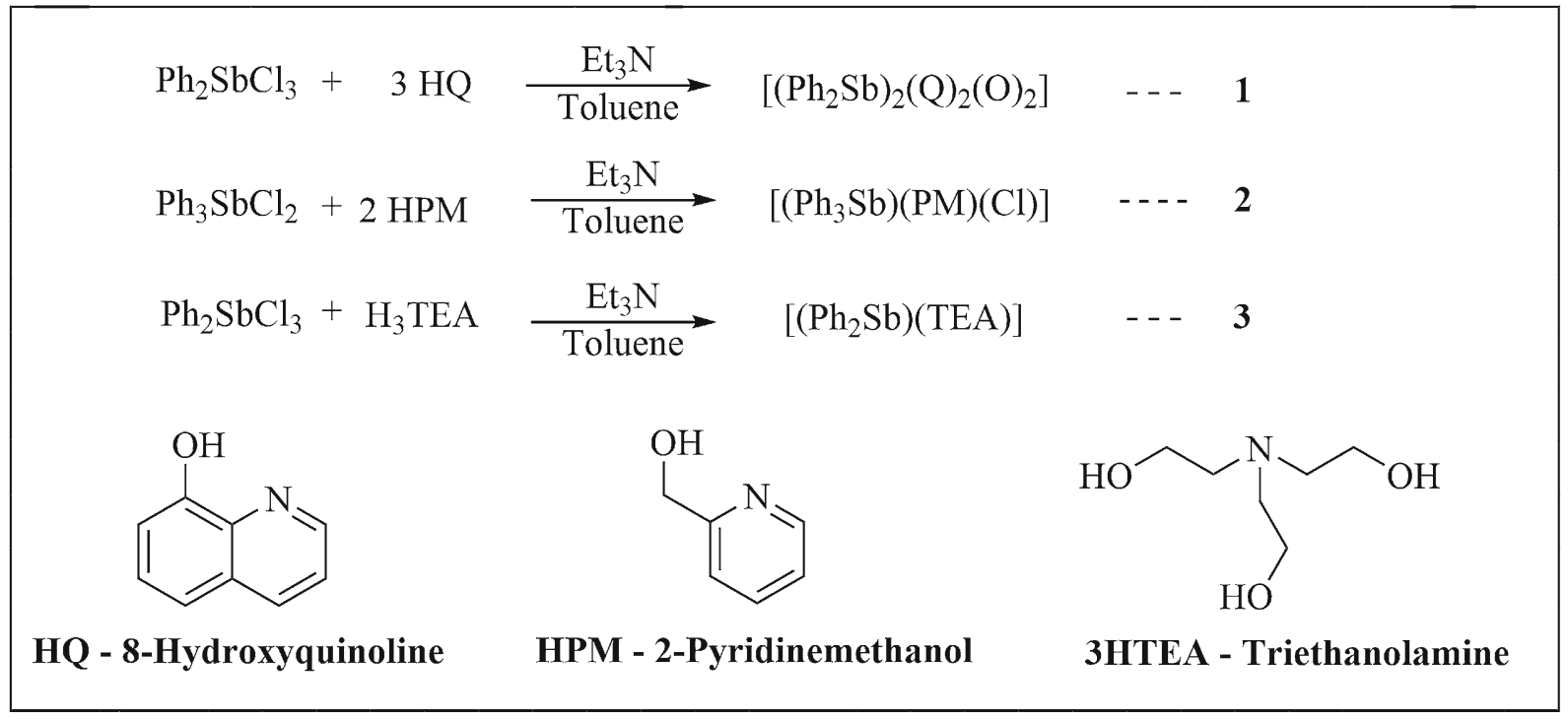

Scheme 1. Synthesis of organoantimony $(\mathrm{V})$ complexes (1-3).

complete spectroscopic and analytical data are given in the experimental section.

\subsection{Crystallographic Analysis}

Single crystal X-ray elucidation reveals the formation of an oxo-bridged dimer in $\mathbf{1}$ (Figure 1). Compound $\mathbf{1}$ crystallizes in orthorhombic space group Pbcn along with a molecule of dichloromethane as a solvent of crystallization. The coordination geometry around $\mathrm{Sb}$ is octahedral. The deprotonated ligand 8-hydroxyquinoline chelates to the metal ion through its $\mathrm{N}$ and $\mathrm{O}$ atom accounting for two coordination sites around the metal center. Two more coordination arises out of the phenyl carbons and the fifth and the sixth coordination are accounted for from the $\mu^{2}$-bridging oxygen atoms satisfying the coordination sphere around the metal atom. This bridging $\mu^{2}$-oxygen which connects the two metal atoms leads to the formation of a four-membered $\mathrm{Sb}_{2} \mathrm{O}_{2}$ ring. Such $\mathrm{Sb}_{2} \mathrm{O}_{2}$ four-membered rings are common structural motifs in organoantimony compounds. ${ }^{6}$ $\mathrm{Ph}_{2} \mathrm{SbCl}_{3}$ is a weak Lewis acid which readily forms $1: 1$ adduct compounds with solvent molecules like water $\left(\mathrm{Ph}_{2} \mathrm{SbCl}_{3} \cdot \mathrm{H}_{2} \mathrm{O}\right)$. We anticipate that a little excess $\mathrm{Et}_{3} \mathrm{~N}$ base used in the reaction deprotonates the coordinated water molecule from the $\mathrm{Ph}_{2} \mathrm{SbCl}_{3} \cdot \mathrm{H}_{2} \mathrm{O}$ and thereby stabilizes the oxo-bridged dimer(1). The $\mathrm{Sb}-\mathrm{O}, \mathrm{Sb}-\mathrm{N}$ bond distances and other metric parameters are given in Table S2 (in Supplementary Information). These bond parameters fall in the range as reported in literature. ${ }^{15}$

Compound 2 crystallizes in monoclinic space group $P 2_{1} / c$ (Figure 2). As in compound $\mathbf{1}$, the geometry around the central metal atom antimony is octahedral. The deprotonated 2-pyridinemethanol ligand chelates



Figure 1. ORTEP plot (30\% probability thermal ellipsoids) of the molecular structure 1. For the sake of clarity, all hydrogen atoms have been omitted.

to the metal atom by replacing a chloride atom from triphenylantimony dichloride while the other chlorine remains attached to the metal ion. In organoantimony $(\mathrm{V})$ chemistry, instances where a chloride ion present can bridge to the metal atom of another molecule leading to the formation of halogen bridged dimers are common. ${ }^{29,30}$ This kind of halogen bridging is also generally accompanied by increasing the coordination numbers to seven or even eight due to hypervalent nature of antimony in +5 state of oxidation. But, probably the bulky nature of the ligand has led to the isolation of a monomeric organoantimony compound. It has 


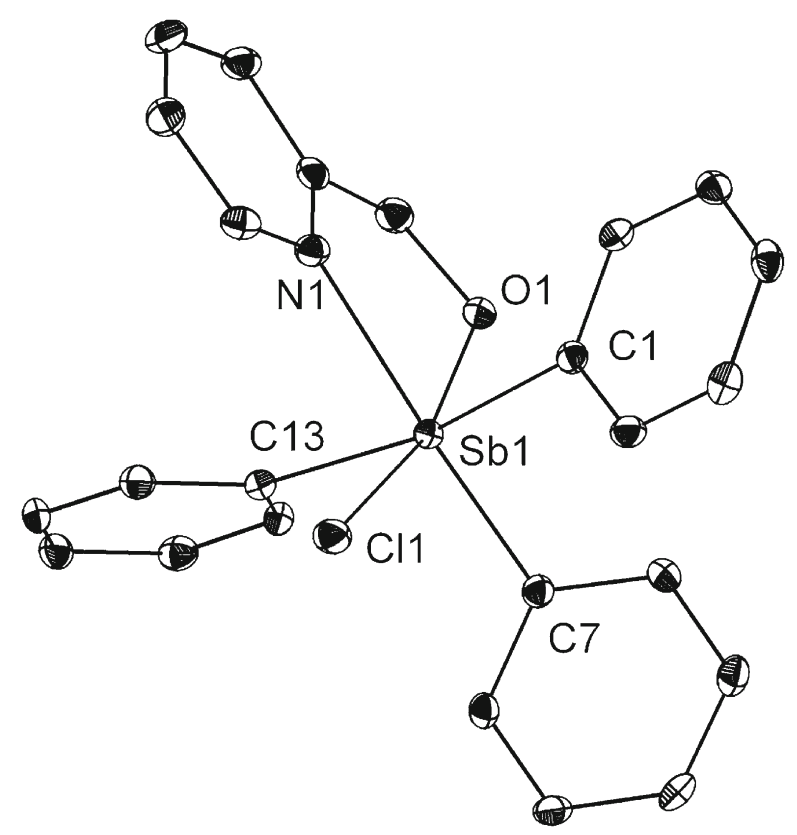

Figure 2. ORTEP plot (30\% probability thermal ellipsoids) of the molecular structure 2. For the sake of clarity, all hydrogen atoms have been omitted.

to be mentioned here that aggregation is not the only way to reach higher coordination numbers around the metal ion in organoantimony compounds as there is a literature report of a hypervalent seven coordinate monomeric organoantimony compound. ${ }^{10}$ Hence, the steric, as well as electronic properties of the ligand in addition to the organic groups bound to the antimony starting material, might play a role in deciding whether or not one can achieve higher coordination number than six in organoantimony compounds. Important metric parameters of $\mathbf{2}$ are given in Table S2. It has to be mentioned here that $\mathbf{2}$ could not be obtained in pure form as small amounts of free ligand always precipitated with $\mathbf{2}$. Hence, elemental analysis and NMR data for $\mathbf{2}$ are not included in the experimental section. Fortunately, small amounts of crystals of $\mathbf{2}$ (free of ligand) could be isolated to elucidate the solid-state structure of $\mathbf{2}$ by single crystal X-ray crystallographic technique.

Compound $\mathbf{3}$ crystallizes in orthorhombic chiral space group $P 2{ }_{1} 2_{1} 2_{1}$ (Figure 3 ). The coordination geometry around the central metal atom is octahedral. The deprotonated triethanolamine ligand coordinates to the metal atom through its oxygen and nitrogen atoms accounting for four coordination sites while the other two coordination is accounted for by the phenyl carbons. Important metric parameters are given in Table S2. Probably due to the steric nature of the ligand used, aggregation leading to the formation of larger clusters has been prevented. It is of interest to mention here that this compound is an example of spontaneous chirality as although both the starting materials are achiral, the end product has crystallized in a chiral space group and hence chiral. The flak parameter also reflects the chirality present in the molecule. When triethanolamine has been used as a ligand in certain transition metal complexes, it has been reported to lead to spontaneous chirality resulting in the crystallization of these transition metal compounds in chiral space group. ${ }^{31,32}$ But, to our knowledge, such reports are uncommon in

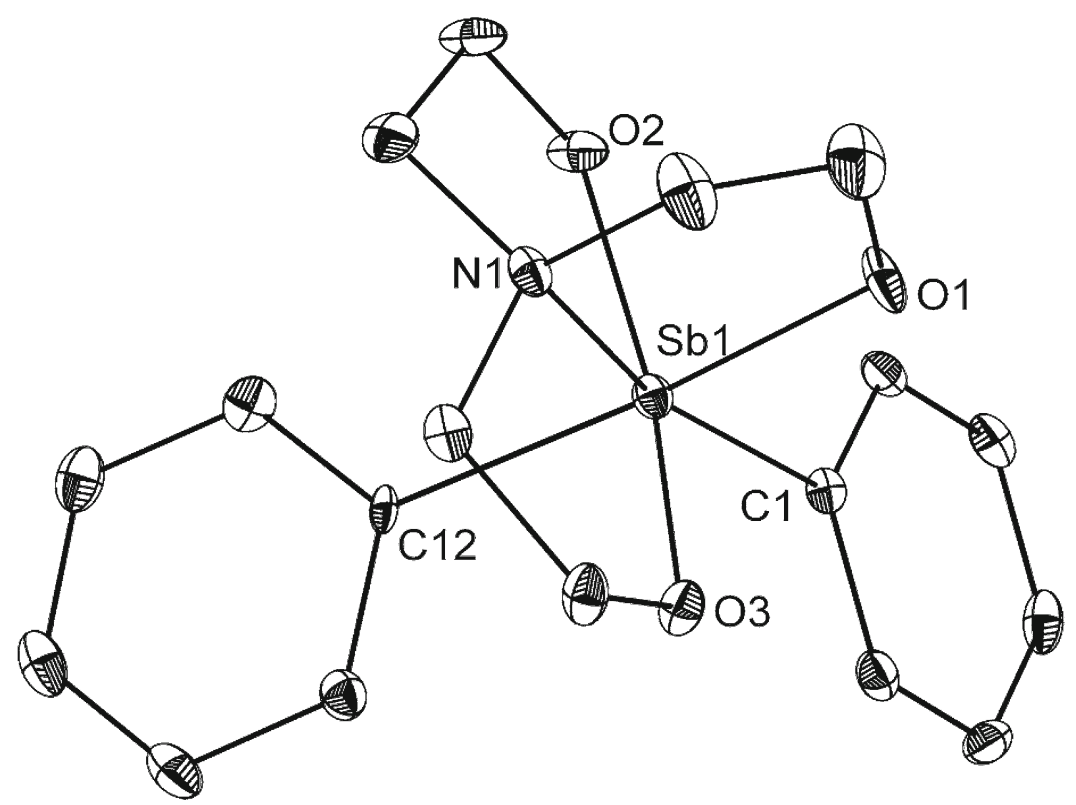

Figure 3. ORTEP plot (30\% probability thermal ellipsoids) of the molecular structure 3. For the sake of clarity, all hydrogen atoms have been omitted. 
organoantimony literature. Hence, this observation of spontaneous chirality is quite unprecedented.

\section{Conclusions}

Investigation of the reactions of di/tri-organoantimony halides with N,O-donor ligands has afforded an oxobridged dimer and two monomeric organoantimony compounds (1-3). When triethanolamine was used as ligand, a monomeric organoantimony compound which crystallizes in chiral space group has been isolated. To our knowledge, this is the first observation of spontaneous chirality in such organoantimony systems. Hydrolytic cleavages of $\mathrm{Sb}-\mathrm{C}$ bonds in 1-3 under mildly acidic conditions are being currently investigated in our laboratory.

\section{Supplementary Information (SI)}

Crystallographic data, structural refinement and selected bond lengths/angles for complexes 1-3, NMR spectra of complex 1 and complex $\mathbf{3}$ are given in Tables S1 and S2. Supplementary Information is available at www.ias.ac.in/chemsci.

\section{Acknowledgements}

V.B. thanks DST for funding under the SERC-Fast track Scheme. P.V.V.N.K. thanks CSIR for a Fellowship.

\section{References}

1. Huang Y Z 1992 Synthetic applications of organoantimony compounds Acc. Chem. Res. 25182

2. Fujiwara Y, Mitani M, Yasuike S, Kurita J and Kaji T 2005 An Organobismuth Compound that Exhibits Selective Cytotoxicity to Vascular Endothelial Cells in Vitro J. Health Sci. $\mathbf{5 1} 333$

3. Yin H D, Wen L Y, Cui J C and Li W K 2009 Synthesis, characterizations and crystal structures of new organoantimony $(\mathrm{V})$ complexes with various isomers of fluoromethylbenzoate ligands Polyhedron 282919

4. Chaudhari K R, Jain V K, Sagoria V S and Tiekink E R T 2007 Triorganoantimony(V) carboxylates: Synthesis, characterization and crystal structure of $\left[\mathrm{Me}_{3} \mathrm{Sb}\left(\mathrm{O}_{2} \mathrm{C}-\mathrm{C}_{5} \mathrm{H}_{4} \mathrm{~N}\right)_{2}\right] \cdot \mathrm{H}_{2} \mathrm{O}$ J. Organomet. Chem. 6924928

5. Silvestru C, Silvestru A, Haiduc I, Sowerby D B, Ebert K H and Breunig H J 1997 Triorganoantimony(V) diorganophosphinates. Crystal and molecular structure of (diphenylphosphinato) (hydroxo) trimethylantimony $(\mathrm{V})$, exhibiting a polymeric chain supramolecular self-assembly through hydrogen bonds Polyhedron 162643

6. Said M A, Kumara Swamy K C, Poojary D M, Clearfield A, Veith M and Huch V 1996 Dinuclear and Tetranuclear
Cages of Oxodiphenylantimony Phosphinates: Synthesis and Structures Inorg. Chem. 353235

7. Chandrasekhar V and Thirumoorthi R 2009 A Nonanuclear Organostiboxane Cage Organometallics 2 2637

8. Liu L, Zakharov L N, Golen J A, Rheingold A L and Hanna T A 2008 Synthesis and Characterization of Bismuth(III) and Antimony(III) Calixarene Complexes Inorg. Chem. 4711143

9. de Oliveira L G, Silva M M, de Paula F C S, PereiraMaia E C, Donnici C L, de Simone C A, Frézard F, da Silva Júnior E N and Demicheli C 2011 Antimony(V) and Bismuth(V) Complexes of Lapachol: Synthesis, Crystal Structure and Cytotoxic Activity Molecules $\mathbf{1 6}$ 10314

10. Said M A, Kumara Swamy K C, Babu K, Aparna $\mathrm{K}$ and Nethaji M 1995 Diphenylantimony(V) oxo/chloro carboxylates and phosphinates: crystal structures of $\left\{\mathrm{SbPh}_{2} \mathrm{Cl}\left[\mathrm{O}_{2} \mathrm{P}\left(\mathrm{C}_{6} \mathrm{H}_{11}\right)_{2}\right]\right\}_{2} \mathrm{O}$ and $\left[\mathrm{SbPh}_{2}\left(\mathrm{O}_{2} \mathrm{CPh}\right)_{2}\right]_{2} \mathrm{O}$ J. Chem. Soc. Dalton Trans. 2151

11. Yu L, Ma Y Q, Wang G C and Li J S 2004 Synthesis and In Vitro Antitumor Activity of Some Triarylantimony Di(N-phenylglycinates) Heteroat. Chem. 1532

12. Li J S, Huang $G \mathrm{Q}$, Wei $\mathrm{Y} \mathrm{T}$, Xiong $\mathrm{C} \mathrm{H}$, Zhu D Q and Xie Q L 1998 Synthesis, characterization and biological activities of some triarylantimony dichrysanthemates and crystal structure of $\mathrm{Ph}_{3} \mathrm{Sb}\left(\mathrm{O}_{2} \mathrm{CCHCMe} \mathrm{CMe}_{2}\right)_{2}$ Appl. Organomet. Chem. 1231

13. Ma Q, Li J S, Xuan Z N and Liu R C 2001 Synthesis, characterization and antitumor activity of some arylantimony triphenylgermanylpropionates and crystal structures of $\mathrm{Ph}_{3} \mathrm{GeCH}(\mathrm{Ph}) \mathrm{CH}_{2} \mathrm{CO}_{2} \mathrm{SbPh}_{4}$ and $\left[\mathrm{Ph}_{3}\right.$ $\left.\mathrm{GeCH}_{2} \mathrm{CH}\left(\mathrm{CH}_{3}\right) \mathrm{CO}_{2}\right]_{2} \mathrm{Sb}\left(4-\mathrm{ClC}_{6} \mathrm{H}_{4}\right)_{3}$ J. Organomet. Chem. 620235

14. Ma Y Q, Yu L and Li J S 2002 Synthesis and biological activity of some triarylantimonydipyrazole carboxylates Heteroat. Chem. 13299

15. Sharma P, Perez D, Vazquez J, Toscano A and Gutierrez R 2007 First example of antimoniated Schiff bases: Hypervalent $\mathrm{Sb} \leftarrow \mathrm{N}(\mathrm{sp} 2)$ bonds Inorg. Chem. Commun. 10389

16. Baskar V, Shanmugam M, Helliwell M, Teat S J and Winpenny R E P 2007 Reverse-Keggin Ions: Polycondensation of Antimonate Ligands Give Inorganic Cryptand J. Am. Chem. Soc. 1293042

17. Ali S, Baskar V, Muryn C A and Winpenny R E P 2008 Mixed antimonate-phosphonate ligands as polydentate bridging oxygen donors Chem. Commun. 6375

18. Prabhu M S R, Jami A K and Baskar V 2009 Organoantimony(V) Oxido Cubane Cluster $\left[\left(\mathrm{p}-\mathrm{X}-\mathrm{C}_{6} \mathrm{H}_{4} \mathrm{Sb}\right)_{4}(\mathrm{O})_{4}\left(\mathrm{Ph}_{2} \mathrm{SiO}_{2}\right)_{4}\right](\mathrm{X}=\mathrm{Cl}, \mathrm{Br})$ Stabilized by Diphenyldisiloxides] Organometallics $\mathbf{2 8}$ 3953

19. Ananda Kumar J, Prabhu M S R and Baskar V 2010 Isolation of Tetranuclear Organoantimony Oxo Clusters and Hexa-decanuclear Polyoxostibonates Organometallics 291137

20. Yin H, Quan L and Li L 2008 Synthesis, spectroscopic and structural aspects of triphenylantimony $(\mathrm{V})$ complex with internally functionalized 
acetylferroceneoxime: Crystal and molecular structures of $\left[\mathrm{C}_{5} \mathrm{H}_{5} \mathrm{FeC}_{5} \mathrm{H}_{4} \mathrm{C}\left(\mathrm{CH}_{3}\right) \mathrm{NO}_{2} \mathrm{SbPh}_{3}\right.$ and $\mathrm{C}_{5} \mathrm{H}_{5} \mathrm{FeC}_{5} \mathrm{H}_{4} \mathrm{C}\left(\mathrm{CH}_{3}\right) \mathrm{NOH}$ Inorg. Chem. Commun. 111121

21. Svoboda T, Jambor R, Ruzicka A, Padelkova Z, Erben M, Jirasko R and Dostal 2010 NCN-Chelated Organoantimony(III) and Organobismuth(III) Phosphonates: Syntheses and Structures Eur. J. Inorg. Chem. 1663

22. Kishore P V V N and Baskar V 2014 Hexa- and Trinuclear Organoantimony Oxo Clusters Stabilized by Organosilanols Inorg. Chem. $\mathbf{5 3} 6737$

23. Srungavruksham N K and Baskar V 2013 Organoantimony(V) Phosphinates, Phosphonates, and Seleninates Eur. J. Inorg. Chem. 20134345

24. Prabhu M S R, Ugandhar U and Baskar V 2016 In situ generated polysiloxanes stabilizing $\mu_{3}$-oxo bridged $\mathrm{Sb}_{3}$ triangles Dalton Trans. 456963

25. Rahman A F M M, Murafuji T, Ishibashi M, Miyoshi Y and Sugihara Y 2004 Effect of $\pi$-accepting substituent on the reactivity and spectroscopic characteristics of triarylbismuthanes and triarylbismuth dihalides $J$. Organomet. Chem. 6893395
26. Bamgboye T T, Begley M J and Sowerby D B 1989 Lewis acidity of $\mathrm{Ph}_{2} \mathrm{SbX}_{3}$, where $\mathrm{X}=\mathrm{Cl}$ or Br. Crystal structures of $\mathrm{Ph}_{2} \mathrm{SbCl}_{3} \cdot \mathrm{H}_{2} \mathrm{O}$ and $\mathrm{Ph}_{2} \mathrm{SbBr}_{3} \cdot \mathrm{MeCN} J$. Organomet. Chem. 36277

27. Bruker. SADABS, SMART, SAINT and SHELXTL, 2000 (Madison, Wisconsin, USA: Bruker AXS Inc.)

28. Sheldrick G M 2008 A short history of SHELX Acta Crystallogr. Sect. A 64112

29. Hubbard C R and Jacobson R A 1972 Molecular bromine bridging of $\mathrm{Sb}^{\mathrm{III}}{ }_{2} \mathrm{Br}_{9}{ }^{3-}$ anions and the crystal structure of tetraethylammonium nonabromodiantimonate(III)dibromine Inorg. Chem. 112247

30. Lawton S L and Jacobson R A 1968 Solution of sodium alloys of some post-transition metals in molten sodium halides. Evidence for anions of bismuth and antimony Inorg. Chem. 72124

31. Nugent W A and Harlow R L 1994 Early Transition Metal Alkoxide Complexes Bearing Homochiral Trialkanolamine Ligands J. Am. Chem. Soc. 1166142

32. Wagner G, Herrmann R and Pombeiro A J L 2002 New chiral terpene-derived vanadatranes Inorg. Chim. Acta 336147 